\title{
Malaysian Consumers Attitude towards Mobile Advertising, the Role of Permission and Its Impact on Purchase Intention: A Structural Equation Modeling Approach
}

\author{
Mohd Nazri Mohd Noor ${ }^{1}$, Jayashree Sreenivasan ${ }^{2} \&$ Hishamuddin Ismail $^{3}$ \\ ${ }^{1}$ Faculty of Business Management, Universiti Teknologi MARA, Pahang Campus, Malaysia \\ ${ }^{2}$ Faculty of Management, Multimedia University, Cyberjaya Campus, Selangor, Malaysia \\ ${ }^{3}$ Faculty of Business and Law, Multimedia University, Melaka Campus, Melaka, Malaysia \\ Correspondence: Mohd Nazri Mohd Noor, Faculty of Business Management, Universiti Teknologi MARA, \\ Pahang Campus, Bandar Tun Abdul Razak Jengka, 26400, Pahang, Malaysia. Tel: 60-13-742-1294. E-mail: \\ nazrizam2003@yahoo.com; mnazri@pahang.uitm.edu.my
}

Received: February 7, 2013 Accepted: March 7, 2013 Online Published: April 27, 2013

doi:10.5539/ass.v9n5p135 URL: http://dx.doi.org/10.5539/ass.v9n5p135

\begin{abstract}
The recent development of a global telecommunication technology provides a new mechanism for companies to promote their products and services. This modern electronic advertising concept is commercially known as mobile advertising. Despite its remarkable opportunities claimed by many quarters, the attitude of Malaysian consumers towards mobile advertising remains unclear. A wise understanding is essential to ensure the effective use of this medium in the future. This study analyzed the consumers' attitude towards mobile advertising and their intention to purchase the advertised products and services. The conceptual framework for this study was derived from the abstract ideas of the Theory of Planned Behavior and the Theory of Permission Marketing. Accordingly, factors such as subjective norms and perceived behavioral control also included to understand its impact on the purchase intention. More importantly, the dimension of permission also included to understand its role between the attitude towards mobile advertising and purchase intention. The convenience sampling technique was applied to obtain responses from the mobile phone users throughout Malaysia. It resulted in 856 usable responses. The analysis of Structural Equation Modeling (SEM) confirmed that the proposed conceptual model fits well within the context of Malaysian consumers. The results of SEM demonstrated significant relationships between the consumers' attitude towards mobile advertising, subjective norms, perceived behavioral control and their intention to purchase products and services. Further analysis also found that the dimension of permission partially mediates the relationship between the attitude and purchase intention. The study reveals several implications for theory and practice relating to the future development of the mobile advertising industry in this country.
\end{abstract}

Keywords: mobile advertising, consumers' attitude, subjective norms, perceived behavioral control, permission, purchase intention

\section{Introduction}

The Malaysian business environment is becoming more competitive. In order to remain competitive, many companies strive to maximize their sales volume and use advertisement to promote their products and services. Generally, traditional advertising still play its role as a popular advertising technique applied by most of the organizations around the world. However, to-date, more and more companies orchestrating a closer harmony between their advertisement messages and mobile communication technology. This new electronic advertising concept is commercially known as mobile advertising (Lane, 2010b). Mobile advertising offers an alternative approach to reach targeted customers more effective and build a stronger and more personal relationship with them (Altuna \& Konuk, 2009; Komulainen, Mainela, Tahtinen, \& Ulkuniemi, 2007). Realizing its great potential, businesses in developed countries are currently taking into account the advantage of mobile advertising to disseminate information about business opportunities and offerings (Frolick \& Chen, 2004; Laszlo, 2009).

According to the white paper published by Smaato in 2010, the mobile advertising industry in developed countries is expected to extend its remarkable take off from 2011 onwards (Lane, 2010c). Based on its current 
trend, the cumulative revenue for five European countries namely France, Germany, Italy, Spain and UK are estimated to achieve US\$\$1.293 billion by 2015 . These big five countries will also experience an increment in revenue by 950 percent between 2010 and 2015 with the compound annual growth rate of 48 percent. Among these countries, UK continues to hold the position as the largest and the most advanced market. On average, each company in UK spends around US\$ $\$ 15,000$ to US\$ $\$ 20,000$ per annum on the campaign. Meanwhile, other companies resided in France, Germany, Italy, and Spain spends approximately US\$ 10,000 to US\$ 15,000 every year. The cumulative total revenue for the big five country is estimated to achieve US\$\$122.55 million. By the end of the year 2011, the European's mobile advertising revenues are expected to reach US\$\$212 million (Lane, 2010c).

Based on the recent market development, Japan and USA remain their position as the market leader in this industry. Besides that, South Korea and China have been identified as the next lucrative market for mobile advertising. The total expenditures for companies in both countries are US\$ 270 million and US\$\$180 million respectively (Lane, 2010a, 2010b). As the biggest market in the world, the mobile advertising expenditure in Japan is around US\$\$ 1 billion every year. On the other hand, USA is blessed with its 'mobile' population exceeding 300 million. The market is currently worth at US\$ 797.6 million and expected to rise up to US\$ $\$ .04$ billion by the year 2015 (Lane, 2010b). In 2010, it was reported that nearly one-sixth or 49 million USA mobile phone subscribers engaged with mobile advertising. From that figure, 12.9 million subscribers act in response towards the advertisement and purchase the offered items (Lane, 2010b). Due to that reason, global brands such as Nike, Adidas, Procter \& Gamble, Microsoft, Coca-Cola, Walt Disney, Sony Pictures, and McDonalds have taken necessary steps to participate in this industry. Two to three percent will be allocated in the annual marketing budget to promote products and services through mobile advertising (Altuna \& Konuk, 2009; Lane, 2010b; Merisavo et al., 2007; Vatanparast \& Asil, 2007).

Within the context of Malaysia, the Malaysian Communications and Multimedia Commission (MCMC) report in 2010 disclosed that the penetration rate of mobile phone was 108.8 percent (Eng \& Masri, 2010). The numbers of mobile phone subscriptions for post-paid were 6.5 million while subscriptions for prepaid were 18.6 million. In the second quarter of 2010, the total numbers of SMS activities were 89.4 million thus indicating a bright potential for Malaysia's mobile advertising activities (Eng \& Masri, 2010). With the phenomenal growth rate of digital media, the Association of Accredited Advertising Agents Malaysia (4As) presumed that more business will move into this industry soon because this approach offers a more reasonable platform to reach consumers effectively (NST, 2009). This statement is supported by the Universal McCann Malaysia (Rozana, 2009) which claimed that, Malaysia ranked fifth out of twenty one concerning consumers' receptivity in the mobile advertising emerging market. Even though the industry is still in its infancy stage (Adham, Said, Ramlee, \& Hannien, 2008), the total revenue is projected to increase from RM 10.04 million in 2008 to RM 175.5 million by the year 2012 (MCMC, 2010).

\subsection{Problem Statement}

Rationally, with such a great number of mobile phone penetration rate in Malaysia, it is easy to utilize the mobile advertising activities among millions of mobile phone users at anytime. Unfortunately, the scenario appears to be in a reverse direction. In 2009, it was reported that the Malaysian consumers' reaction towards mobile advertising in some way not as anticipated by many quarters (MCMC, 2009). Despite various mobile advertising campaigns, MCMC continues to receive various types of complaints from consumers such as the unsolicited advertisement messages, deceptive advertisements, unreasonable charge and difficulties to terminate the subscribed content (MCMC, 2009). Even though the number was relatively small, those complaints must be well thought-out to rectify the translucent potential of mobile advertising in Malaysia. According to Adham, et al. (2008), the issue probably due to the mixed opinion about electronic based business transactions in this country and certainly it was related to the attitude of the consumer.

Another noticeable issue, while the number of mobile advertising grows exponentially, only 14 percent of the mobile phone subscribers involved in the business transactions (Adham, et al., 2008). Though mobile advertising has been regarded as the fifth most influential advertising medium, it seems that the effect of mobile advertising has been over-estimated (Wong \& Tang, 2008). For instance, the Malaysian consumers' response towards mySMS information service was quite stumpy. This is one of the initiatives inspired by the Malaysian Administrative Modernization and Management Planning Unit (MAMPU) for consumers to obtain information about education, social, business, health services, commodities, security, government agencies and many more. Certain fees will be charged to consumers who acquire the service via mobile phone (MAMPU, 2009). However, in 2010 and 2011, only 185 and 190 transactions were recorded by the agency (DOSM, 2011). Indirectly, it reflects the lackluster response from the consumers. 
Based on this phenomenon, again the central issue of the low business transactions, unfavorable responses and under-utilization of mobile phone-based transactions in Malaysia reflects the attitude of the consumers. Despite remarkable opportunities claimed by many quarters (Adham, et al., 2008; Rozana, 2009), the attitude towards mobile advertising must be comprehensively examined. A wise understanding on this issue is essential to ensure an effective use of mobile advertising in the future. Even though studies related to the consumers' attitude had been done in developed countries, findings derived from those countries may not necessarily the same with developing countries (Austin, 1990). Since the Malaysian consumers' attitude towards mobile advertising and their desire to purchase the advertised products and services remain unclear, it is necessary to gain a better understanding about the underlying factors that will shape their attitude which in turn stimulate the intention to purchase. It is also noteworthy to comprehend the significance of prior permission in mobile advertising activities in this country.

\subsection{The Significance of the Study}

This study is significant because mobile phone subscriptions for the past five years in Malaysia have shown an increasing trend (Eng \& Masri, 2010). Studies in other countries found an immense potential of mobile advertising to succeed in conjunction with high penetration and subscriptions rate (Adham, et al., 2008; Basheer \& Ibrahim, 2010; Beneke, Cumming, Stevens, \& Versfeld, 2010; Friedrich, Grone, Holbling, \& Peterson, 2009; Gao, Sultan, \& Rohm, 2010; Jayawardhena, Kuckertz, Karjaluoto, \& Karjaluoto, 2009; Kim, Heo, \& Chan-Olmsted, 2010; Laszlo, 2009; Merisavo et al., 2010). The widespread of various telecommunication devices for communication purposes have changed the nature, reach, velocity and locus of individual's behavior (Bandura, 2001; Mort \& Drennan, 2007; Muk, 2007; Ratten \& Ratten, 2007). Due to that reason, it is essential to study the attitude and consumers' intention to ensure future promotional programs conducted via mobile devices can be accepted without prejudice (Laszlo, 2009; Muk \& Babin, 2006; Nysveen, Pedersen, \& Thorbjornsen, 2005).

This study is conducted in Malaysia to coincide with statements and suggestions made by the Malaysian Communications and Multimedia Commission (MCMC, 2009), Universal McCann Malaysia (Rozana, 2009) and the Association of Accredited Advertising Agents Malaysia (NST, 2009). This research is significant because insofar, there is no such systematic study about consumers' attitude towards mobile advertising purchase intention within the context of Malaysia (MCMC, 2009; Rozana, 2009). Consumers continuously receive mobile advertising (i.e. SMS and MMS advertisements) ranging from reminder, notice, greetings, promotional campaign, new-product launch and also services rendered by various types of companies in Malaysia. However, studies about the underlying factors that will make them open up the advertisement, read, response or keep it for future purchase reference is still insufficient (Adham, et al., 2008).

There were a number of studies discussed the role of permission in mobile advertising (Bamba \& Barnes, 2007; Jayawardhena, et al., 2009; Karjaluoto, Lehto, Leppaniemi, \& Jayawardhena, 2008; Krishnamurthy, 2001; Maneesoonthorn \& Fortin, 2006). However, how the dimension of permission mediates the relationship between attitude and purchase intention remain unclear. Only a little amount of attention is given on this issue (Tsang, Ho, \& Liang, 2004; Wong \& Tang, 2008). Due to the intensifying concern among the consumers towards the unsolicited promotional campaign (MCMC, 2009), the dimension of permission should be taken into account to understand its role to mediate the attitude and how it reflects the intention to purchase.

This study is also parallel to the Malaysian Government Economic Transformation Programme as pronounced by the Prime Minister of Malaysia in Chapter 13: Communications, Content and Infrastructure (PEMANDU, 2010). For years, the Government of Malaysia has put an effort to create a platform for the telecommunication industry to become more competitive and increase the penetration rate. In the World Economic Forum 2009-2010, the global research disclosed that, there was a direct relationship between the growth rate of Gross Domestic Product (GDP) and the penetration of communication services. With a strong recognition on mobile communication services, mobile advertising will become the key infrastructure for the $21^{\text {st }}$ century (WEF, 2010). Prior studies found that, the increment of 10 mobile phones per 100 populations will increase the GDP growth rates by 0.8 percent, and every RM 1 spent on mobile services will generate RM 3 in mobile phone-related sectors (PEMANDU, 2010). Due to that reason, the Government of Malaysia is currently encouraging businesses and consumers to take part in the unified mobile and online payment system. This activity will assist them to save their time and cost while at the same time supporting the green technology campaign (MCMC, 2010). As the mobile-based communication service is becoming part of the Government Economic Transformation Program, consumers should give a full support to ensure that the mission can be achieved. For that reason, this research is significant to assist the government agencies, companies and telecommunication service providers to gain better understanding about the attitude of consumers and prerequisite concerning the implementation of unified mobile 
business transactions in the future.

\subsection{Review of Literatures}

Mobile advertising is expected to become as popular as the internet marketing due to its mobility characteristics and consumers' attitude (Yang, 2007). A study by Bauer, et al. (2005) disclosed that consumers' attitude is one of most important factors in mobile marketing research. A number of studies revealed that consumers who have positive attitudes on advertising will also portray the same attitude upon any specific advertisements (i.e. mobile advertisements) and very much easier to be persuaded (Bauer, Barnes, Reichardt, \& Neumann, 2005; Lutz, 1985; Mehta, 2000; Spurgeon, 2005). Conversely, if they have negative attitude towards general advertising, there will portray a negative reaction against mobile advertising (Drossos, Giaglis, Lekakos, Kokkinaki, \& Stavraki, 2007; Lee, Tsai, \& Jih, 2006). Nonetheless, those statements are consistent with findings reiterated by Ajzen (1991) which stated that attitude has a significant contribution towards prediction of intention. In other words, intention is directed by individual's attitude (Bagozzi, 1981).

Generally, attitude towards certain behavioral intention can be defined as individual's positive or negative feelings about performing the targeted behavior (Davis, Bagozzi, \& Warshaw, 1989; Fishbein \& Ajzen, 1975; Taylor \& Todd, 1995a). Other researchers defined attitude as a mental state used by individuals to structure the way they perceive their environment and guide the way they respond to it (Aaker, Kumar, \& Day, 1995). McKenzie and Lutz (1989) further elaborated the definition by stating that attitude is consumers' learned predisposition to respond in a consistently favorable or unfavorable manner towards advertising in general. Meanwhile, Venkatesh et al. (2003) described attitude as individual's overall affective reaction to use a particular system in conjunction with their studies that focusing on the acceptance of information technology.

Within the context of mobile advertising, previous studies revealed that consumers' attitude on advertisement has a significant effect on their intention to participate or to purchase products and services (Ashraf \& Kamal, 2010; Churchill \& Iacobucci, 2002; Drossos, et al., 2007; Okazaki, 2004; Radder, Pietersen, Wang, \& Han, 2010; Rettie, Grandcolas, \& Deakins, 2005; Yang, 2007). Attitude can be negative or positive, and it is based on the consumers' perception (Bauer, et al., 2005; Chowdhury, Parvin, Weitenberner, \& Becker, 2006). However in some conditions, relationship between attitude and intention can be different (Nysveen, et al., 2005), less stable and can be easily changed (Bauer, et al., 2005). The positive or negative attitude depends on situation or factors that influence them during the time they want to perform a particular behavior (Carroll, Barnes, Scornavacca, \& Fletcher, 2007; Lee, et al., 2006). Past literatures portrayed an interesting pattern about consumers' attitude towards mobile advertising and usually indicated mixed findings from one research to another (Hoyer \& MacInnis, 2004; Schlosser, Shavitt, \& Kanfer, 1999).

Meanwhile, according to the Social Cognitive Theory (Bandura, 1986, 2001), the thought and action of an individual may happen vicariously due to the process of observing the behavior of others and its outcome. The ability to learn through observation permit individuals to obtain principles for generating and shaping their behavioral patterns while at the same time avoiding unnecessary trial and error (Bandura, 2001). Further to that, consumers also refer to others within their circle to gain approval pertaining to their behavior (Pavlou \& Stewart, 2000). Many studies explained this process using various terms such as subjective norms, social norms, social influence, modeling or reference group (Ajzen, 1985, 1991; Ajzen \& Fishbein, 1980; Bandura, 1977, 1978, 1986, 2001; Muk, 2007; Pavlou \& Stewart, 2000; Radder, et al., 2010; Venkatesh, Morris, Davis, \& Davis, 2003). Subjective norm or normative belief can be easily understood as consumers' belief about normative expectations from other people or reference group that live around them (Ajzen, 1985, 1991, 1998). According to Ajzen (1985, 1991, 1998), subjective norm play its role as one of the important constructs that guides future consumers' behavioral intention. In other words, consumers' intention to perform a particular action is based on the function of subjective norm or their perception that other people think they should do (Pavlou \& Stewart, 2000; Solomon, 2004).

Regardless education level, age and gender, many groups of people exist to influence consumers' thought and action (Bandura, 1986). These groups will extensively influence consumers' behavior (Blackwell, Miniard, \& Engel, 2001; Compeau \& Higgins, 1995a, 1995b; Evans, Jamal, \& Foxall, 2006; Shimp \& Kavas, 1984) and generally comprises of consumer's family members, friends or colleagues at their workplace (Blackwell, et al., 2001; Katz, Hass, \& Gurevitech, 1973; Kotler \& Armstrong, 2001; McDaniel, Lamb, \& Hair, 2006; Pavlou \& Stewart, 2000). Since they usually hold a remarkable credibility, consumers always refer to these groups to obtain an opinion about their activities (Bandura, 1986; Compeau \& Higgins, 1995a, 1995b; Teo \& Pok, 2003). Subjective norms also act as the catalyst to expose prospective consumers into a new lifestyle. It may influence consumers' behavior and create pressures to encourage their choices related to offerings made by businesses. 
Within the context of mobile advertising, subjective norms usually play its role to encourage consumers to purchase products and services that appear in their mobile phones (Zhang \& Mao, 2008).

Subjective norms, social norms, social influences, modeling, normative pressure or reference group have been regarded as an important element in many innovation diffusion literatures (Cooper \& Zmud, 1990; Hung, Ku, \& Chang, 2003; Khan \& Allil, 2010; Laudon, 1985; Nysveen, et al., 2005; Teo \& Pok, 2003; Triandis, 1979). According to marketing literatures, subjective norms has a significant positive influence on the consumers' behavioral intention such as intention to adopt an innovation or to purchase products and services (Ajzen, 1991; Bagozzi, Wong, Abe, \& Gergami, 2000; Davis, et al., 1989; Hartwick \& Barki, 1994; Mathieson, 1991; Muk, 2007; Nysveen, et al., 2005; Radder, et al., 2010; Teo \& Pok, 2003; Venkatesh \& Davis, 2000; Venkatesh, et al., 2003; Yang, 2007). A study by Triandis (1971) revealed that subjective norm plays a vital role, especially when the behavior is new and still at the early phase of development. Consumers with lack of experience also found to rely heavily on the opinion of reference groups to engage (Mowen \& Minor, 2001; Triandis, 1971, 1979; Zhang $\&$ Mao, 2008) or to reduce uncertainty upon adopting a particular innovation (Baron \& Byrne, 2000; Muk \& Babin, 2006). Parallel to the suggestion made by Ajzen (1991) and Davis, et al. (1989), Tripathi and Siddiqui (2008) and Bagozzi, et al. (2000) reiterated that consumers' socio-cultural environment (i.e. family, informal sources, culture and sub-culture) which is also similar to the subjective norm found to have a significant impact on their purchase decision.

In another aspect, behavioral control plays an important role to understand consumers' perception, whether a particular behavioral act is within their control or vice-versa (Ajzen, 1991; Blackwell, et al., 2001; Pavlou \& Stewart, 2000). This construct has been used by many studies along with the intention to predict consumers' behavior in the future (Ajzen, 1985; Thomas, Ellen, \& Ajzen, 1992). Behavioral control can be defined as an individual's perceptions related to internal and external constraints on behavior, including resources and technology facilitating conditions (Ajzen, 1991; Taylor \& Todd, 1995a; Triandis, 1979). In other words, consumers' intention will be directed by their beliefs regarding the existence of factors that might assist or hinder the performance of a particular behavior (Hongwei, Zhou, \& Liu, 2010; McKenzie \& Jurs, 1993). Carroll, et al. (2007) suggested that control can be in the form of information privacy control such as consumers' control over the disclosure and dissemination of information. Control can also be in the shape of physical privacy such as consumers' control over unrequested physical and media disturbances (Carroll, et al., 2007).

Furthermore, consumers require fair opportunities to have control over the transaction process to boost their confidence for further business deals (Leppaniemi \& Karjaluoto, 2005; Milne \& Rohm, 2000; Okazaki, Li, \& Hirose, 2009). Prior to that, consumers' knowledge about how to utilize mobile communication technologies together with technology facilitating conditions also found to be equally important to ensure participation in mobile advertising activities (Beneke, et al., 2010; Nysveen, et al., 2005). There were studies that classified behavioral control in the form of consumers' self-regulatory and voluntary control (Bandura, 2001; Rose, 2006). As mentioned earlier, self-regulatory arbitrate external influences and offer a good foundation for purposeful action hence permitting individuals to have personal control over their personal thoughts, feelings, motivations and actions (Bandura, 1986, 2001). This control is very important because it provides a mechanism that governs what behavior that is going to be performed and self-imposed consequences for that behavior (Bandura, 2001). Meanwhile, voluntary means the opportunity given to consumers for them to decide whether to participate or not to participate with a particular innovation (Ajzen, 1991; Bamba \& Barnes, 2007; Kim, et al., 2010; Yang, 2007). Prior literatures revealed that consumers' ability on behavioral control has a significant positive influence on many behavioral intentions (Bauer, et al., 2005; Carroll, et al., 2007; Hongwei, et al., 2010; Leppaniemi \& Karjaluoto, 2005; Merisavo, et al., 2010; NOKIA, 2002; Nysveen, et al., 2005; Sheppard, Hartwick, \& Warshaw, 1988; Tripathi \& Siddiqui, 2008; Tsang, et al., 2004; Venkatesh, et al., 2003). In fact, studies in developed countries disclosed that many consumers appreciate rights to have behavioral control (Hongwei, et al., 2010; Leppaniemi \& Karjaluoto, 2005; Okazaki, et al., 2009).

Intention can be defined as subjective judgments about how a person will behave in the future (Blackwell, et al., 2001; Granbois \& Summers, 1975; Miniard, Obermiller, \& Page, 1983; Reibstein, 1978). Intention provides an informative indication of a particular business to succeed while retaining its customers (Blackwell, et al., 2001). It is common that consumers usually do what they intend to do. Parallel to that reason, many previous studies have shown that intention provides a significant prediction of how people behave in the future (Altuna \& Konuk, 2009; Drossos, et al., 2007; Morwitz, Johnson, \& Schmittlein, 1993; Park, Shenoy, \& Salvendy, 2008; Taylor \& Baker, 1992; Taylor \& Todd, 1995b; Warshaw, 1980; Weilbacher, 2003). From the perspective of marketing, purchase intention is part of consumers' intention (Blackwell, et al., 2001) and very helpful to act as an indicator for many marketing activities (Altuna \& Konuk, 2009). Purchase intention reflects what consumers think they 
will buy in future to fulfill their needs and wants (Blackwell, et al., 2001). However, consumers' intention may change due to unanticipated circumstances (Joseph, James McCullough, \& Reilly, 1985). Thus, it is important for businesses to take proactive measures (Ajzen \& Fishbein, 1977; Jaccard, King, \& Pomozal, 1977) to ensure that their customers have a positive perception about products and services (Blackwell, et al., 2001; Kotler \& Armstrong, 2001; McDaniel, et al., 2006). Often, consumers' purchase intention will be based on the advertising approach, their attitude and how much they know about offerings highlighted by a particular business (Blackwell, et al., 2001; Jun \& Lee, 2007; Park, et al., 2008; Peng, 2006; Wong \& Tang, 2008).

The term permission marketing was introduced by Godin (1999). The fundamental concept of permission marketing connotes that consumers will give businesses a permission to deliver them certain types of promotional messages (Godin, 1999). Within the context of mobile marketing, permission is the initiation of a two way mobile interactions between customers and businesses via mobile phones (Jayawardhena, et al., 2009). Blackwell, et al. (2001), described permission marketing as the process of persuading consumers to pay their attention in return for some tangible benefits. The other researchers illustrate permission as a dynamic boundary shaped by a combination of consumers' personal preferences (Barnes \& Scornavacca, 2004). In some countries, permission marketing becomes very important until it is impossible to perform mobile advertising campaign without explicit permission from consumers (Kautonen, Karjaluoto, Jayawardhena, \& Kuckertz, 2007). According to Krishnamurthy (2001), the basic business model of permission marketing is very much related to direct relationship maintenance. This model depicts that consumers will sign up for a promotional campaign alerts if they are required to furnish uncomplicated information. For that reason, business must request simple information to make the advertisement more effective and increase the rate of acceptance. This concept will also help to cultivate a stronger relationship between consumers and business entities.

\subsection{Hypotheses Development}

\subsubsection{Attitude towards Mobile Advertising}

The Theory of Planned Behavior (Ajzen, 1991, 1998) postulated that the more favorable the attitude with respect to a behavior, the stronger will be an individual's intention to perform the behavior under consideration. A study by Wong and Tang (2008) disclosed that consumers' attitude towards mobile advertising became a significant factor that influences consumers' intention to receive and read mobile advertisements. Meanwhile, a multivariate analysis conducted by Tsang et al. (2004) revealed that consumers' attitude significantly correlated with their intention to receive mobile advertisement. The attitude towards advertisement also played a vital role towards their willingness to access the advertisement (Okazaki, 2004). In fact, the dimension of attitude portrayed the highest magnitude of regression weight thus indicating that it was the most determining factor of consumers' behavioral intention to click the advertisements (Okazaki, 2004).

There were also studies related to the attitude towards general advertising and mobile advertising on the behavioral intention to use mobile marketing services (Bauer, et al., 2005). Findings depicted that the attitude towards advertising in general and the attitude towards mobile marketing strongly determined the consumers' intention to participate in mobile marketing services (Bauer, et al., 2005; Radder, et al., 2010). Muk and Babin (2006) studied the attitude towards accepting wireless advertisements and their intention to adopt SMS advertisement. The result signified that the attitude towards accepting the wireless advertisements turned out to be significant predictors on the intention to opt-in to SMS advertising (Muk \& Babin, 2006). Therefore, it is predicted that Malaysian consumers' attitude towards mobile advertising has a significant relationship with their intention to purchase products and services. This gives rise to the next hypothesis:

H1: Consumers' attitude towards mobile advertising has a significant relationship with the intention to purchase products and services.

\subsubsection{Subjective Norm}

Subjective norm is a dimension highlighted in the Theory of Planned Behavior model (Ajzen, 1991). It is common that consumers refer to people around them to obtain endorsement about their behavioral attitude (Pavlou \& Stewart, 2000). Many studies explained this scenario and labeled it as "subjective norms" (Ajzen, 1985, 1991; Ajzen \& Fishbein, 1980; Bandura, 1977, 1978, 1986, 2001; Muk, 2007; Pavlou \& Stewart, 2000; Radder, et al., 2010; Venkatesh, et al., 2003). The term referred to as individuals' belief about the expectation which came from the influential people or reference group that exists around them (Ajzen, 1985, 1991, 1998). According to Ajzen $(1985,1991,1998)$, subjective norm is an important dimension that guide future behavioral intention. Previous studies revealed that, the intention to perform a particular action is based on the subjective norm's perception about what a person should do (Pavlou \& Stewart, 2000; Solomon, 2004). 
A study by Bauer et al. (2005) found that consumers' behavioral intention to accept mobile phone as an innovative media for advertisement is positively influenced by subjective norm. This dimension also found to have a significant positive effect on the intention to use the person-interactive mobile services such as contact and text messaging, especially among the older consumers (Nysveen, et al., 2005). Concerning the social influences on the intention to opt-in to SMS advertising, Muk and Babin (2006) and Radder et al. (2010) disclosed that there was a strong relationship between both dimensions. Zhang and Mao (2008) discovered that this dimension played a vital role for the Chinese consumers' intention to read and take action based on the suggestion made by the advertisement. The same result also produced by Khan and Allil (2010) which revealed that subjective norm act as an important determinant of consumers' intention to adopt mobile advertising. For that reason, it is notable to predict that subjective norm will also have a positive effect among the Malaysian consumers' intention to purchase products and services. Thus, the next hypothesis is as follows:

H2: Subjective norms positively influence the consumers' intention to purchase products and services as advertised in mobile advertising.

\subsubsection{Perceived Behavioral Control}

Perceived behavioral control can be understood as a person's perceptions based on the internal and external constraints, including resources and technology facilitating conditions (Ajzen, 1991; Taylor \& Todd, 1995a; Triandis, 1979). Consumers' behavioral intention usually directed by their beliefs due to the existence of constraints, which may assist or hinder the act of a particular behavior (Hongwei, et al., 2010; McKenzie \& Jurs, 1993). Consumers always require fair opportunities to have control over a specific transaction process to boost their confidence for further business deals (Leppaniemi \& Karjaluoto, 2005; Milne \& Rohm, 2000; Okazaki, et al., 2009).

According to Khan and Allil (2010), perceived behavioral control played an important role towards the intention to adopt mobile advertising. Behavioral control also found to portray a significant result during the formation of consumers' intention towards the acceptance of mobile text message advertisement Beneke et al. (2010). In addition to that, consumers' perception about their ability to control over the number, the selection of services and type of mobile messages produced a positive effect on their engagement with mobile advertisement (Jayawardhena, et al., 2009; Maneesoonthorn \& Fortin, 2006; Vatanparast \& Asil, 2007). A study by Nysveen et al. (2005) disclosed that perceived behavioral control has a positive relationship with the intention to use goal-directed mobile services than the intention to use experiential mobile services regardless of gender and age. Caroll et al. (2007) and Merisavo et al. (2007) reiterated that, consumers' opportunity to control over the content, time and frequency of the messages will lead towards the acceptance of mobile advertising. Therefore, it can be predicted that consumers perceived behavioral control against mobile advertising will portray a positive relationship on their purchase intention. The next hypothesis is as follows:

H3: Consumers perceived behavioral control positively influence their intention to purchase products and services as advertised in mobile advertising.

\subsubsection{Permission}

Many consumers treat mobile phone as their valuable private belongings (Bamba \& Barnes, 2007; Barnes \& Scornavacca, 2004; Barwise \& Strong, 2002; Hulme \& Peters, 2001; Whitaker, 2001). Hence, permission plays an important role to inculcate their positive view about mobile advertising (Bauer, et al., 2005; Kavassalis et al., 2003; Wong \& Tang, 2008). Previous literatures concerning marketing and advertising suggested that the dimension of permission has a significant effect on the consumers' behavioral intentions (Abernethy, 1991; Dufrene, Engelland, Lehman, \& Pearson, 2005). Permission was also found to act as a mechanism that lessened consumers' irritation on the advertisement (Li, Edwards, \& Lee, 2002; Tsang, et al., 2004), and very practical for building and strengthening a "business-consumers" relationship (Barnes \& Scornavacca, 2004; Godin, 1999; James, Griffiths, Smyrnios, \& Wilson, 2004). Indeed, consumers have more desire to deal with advertisers who provide clearer instruction about their permission marketing policy (Kavassalis, et al., 2003). As a result, they tend to ignore advertisement that appears without prior permission (Denk \& Hackl, 2004; Varshney, 2003; Wang \& Wang, 2005). In reality, the key success factor of mobile marketing depends on the consumers' permission (Barnes \& Scornavacca, 2004; Carroll, et al., 2007). According to Tripathi and Siddiqui (2008), sending an advertisement without prior consent tarnished the mobile advertising industry. Previous literatures revealed that the dimension of permission has a significant effect on the relationship between consumers' attitude and the intention to purchase products and services (Barwise \& Strong, 2002; Kavassalis, et al., 2003; Tsang, et al., 2004; Wong \& Tang, 2008). This dimension was found to be among the most influential factor rated by consumers (Carroll, et al., 2007). With permission, consumers' will have more confidence to participate in the purchase 
activities (Okazaki, 2004; Tsang, et al., 2004). Therefore, it can be predicted that the dimension of permission plays a vital role to mediate the relationship between attitude towards mobile advertising and consumers' purchase intention. The hypothesis is as follows:

H4: The relationship between consumers' attitude towards mobile advertising and purchase intention is mediated by prior permission.

\section{Research Methodology}

This study aims to understand the Malaysian consumers' attitude towards mobile advertising, to comprehend the role of permission and its impact on consumers' purchase intention. To proceed, this study attempts to correlate the independent, mediating and dependent variables as depicted in the proposed conceptual framework (Figure 1). The study was conducted in the natural environment where work proceeds with non-contrived setting in the field studies (Roscoe, 1975; Sekaran, 2003).

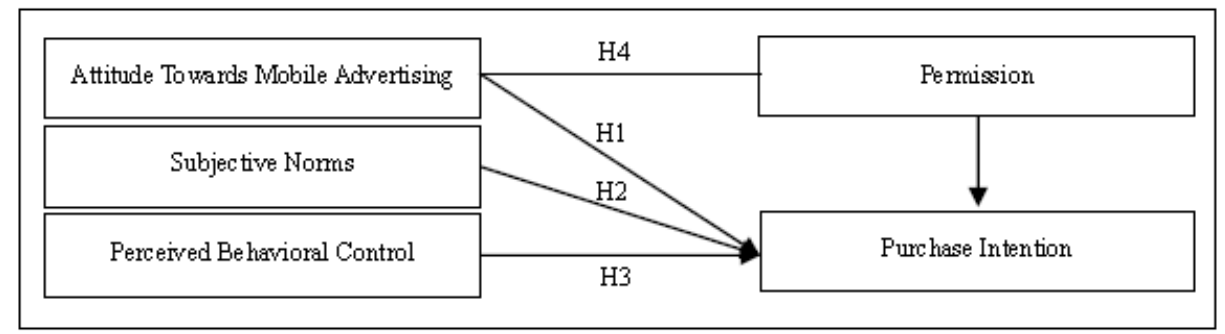

Figure 1. Proposed conceptual framework

The unit of analysis is essential to depict the level of aggregation of the data collected during the subsequent data analysis stage (Sekaran, 2003). Here, the main interest is to study the individual decision making. Therefore, the mobile phone users became the subject for this study. It covers thirteen states and three federal territories in Malaysia. Based on the information obtained from Eng \& Masri (2010) and MCMC (2010), the number of mobile phone subscribers in Malaysia became the basis for the sampling design (Table 1).

Table 1. The number of mobile phone subscribers in Malaysia (2010)

\begin{tabular}{cccc}
\hline State & No. of Subscribers & State & No. of Subscribers \\
\hline Perlis & $219,501(0.87 \%)$ & Terengganu & $648,522(2.58 \%)$ \\
Kedah & $1,715,881(6.82 \%)$ & Kelantan & $1,086,958(4.32 \%)$ \\
Pulau Pinang & $1,583,242(6.30 \%)$ & Sarawak & $1,623,539(6.46 \%)$ \\
Perak & $2,021,006(8.04 \%)$ & Sabah & $1,825,103(7.26 \%)$ \\
Selangor & $5,265,504(20.94 \%)$ & & No. of Subscribers \\
Negeri Sembilan & $943,463(3.75 \%)$ & Federal Territories & $2,552,655(10.15 \%)$ \\
Melaka & $843,280(3.35 \%)$ & Kuala Lumpur & $73,861(0.29 \%)$ \\
Johor & $3,391,811(13.49 \%)$ & Putrajaya & $52,145(0.21 \%)$ \\
Pahang & $1,296,706(5.16 \%)$ & Labuan & $\mathbf{2 5 , 1 4 3 , 1 7 7}$ \\
\end{tabular}

\subsection{The Sampling Design}

The mobile phone users from each state and federal territories were deemed likely to provide a broad cross-section of experience with mobile phone usage and represent diversity in demography. Apart from their wide cross section, these populations also have an extensive exposure towards mass media and technology. In addition to that, these populations practice a prudent social interaction among themselves. According to Rogers \& Kincaid (1981), a community with a higher degree of social interactions will have higher tendency to adopt new innovations than those who have a lower degree of social interactions.Based on the suggestion made by Kerjcie and Morgan (1970), the sufficient number of sample size for population more than 1 million is 384 . This 
study aims to acquire 384 or more responses to gain better and representative results. Generally, mall intercept survey may offer high-volume responses than other methods and the rate of response usually between 20 to 30 percent (Freeman, 2008; Kervin, 1992; Rich \& Hancock, 2005) Therefore, 1,600 sets of questionnaires were distributed throughout Malaysia to achieve the suggested number of sample size. Table 2 indicates the proportionate distribution of questionnaires based on the number of subscribers. The researcher came close to all respondents following the method of convenience sampling. Sekaran (2003) suggested that, convenience sampling is suitable if the number of population is large. It offers a quick and convenient for the researcher to get an immediate response. Most importantly, this sampling method ensures an adequate number of respondents that can be selected from each state and federal territories.To acquire the primary data, the researcher conducted an intercept survey at major shopping mall and public transport station. Respondents were asked to provide necessary information about them in the questionnaire form. Data collection activities were done throughout November 2011 - April 2012. The researcher performed a one-shot or cross-sectional data collection to find out the answers to all anticipated research questions.

Table 2. The proportionate distribution of questionnaires

\begin{tabular}{cccc}
\hline State & No. of Subscribers & State & No. of Subscribers \\
\hline Perlis & $14(0.87 \%)$ & Terengganu & $41(2.58 \%)$ \\
Kedah & $109(6.82 \%)$ & Kelantan & $69(4.32 \%)$ \\
Pulau Pinang & $101(6.30 \%)$ & Sarawak & $103(6.46 \%)$ \\
Perak & $129(8.04 \%)$ & Sabah & $116(7.26 \%)$ \\
Selangor & $335(20.94 \%)$ & Federal Territories & No. of Subscribers \\
Negeri Sembilan & $60(3.75 \%)$ & Kuala Lumpur & $162(10.15 \%)$ \\
Melaka & $54(3.35 \%)$ & Putrajaya & $5(0.29 \%)$ \\
Johor & $216(13.49 \%)$ & Labuan & $3(0.21 \%)$ \\
Pahang & $83(5.16 \%)$ & & $\mathbf{1 , 6 0 0}$ \\
\hline
\end{tabular}

\subsection{Survey Instrument}

As this study sought to test the proposed conceptual model, some of the survey instruments were adapted and modified from the previous studies. The survey contained several constructs related to the consumers' attitude towards mobile advertising, purchase intention, including subjective norms, perceived behavioral control and permission. Prior to administering the survey, it was reviewed by five experts from the industry and university lecturers for clarity and applicability to the topic investigated. Overall, the survey designed 29 questions to gauge the consumers' attitude as well as classification questions related to gender, age and education level. Each construct was represented by Likert scale items adapted from the previous studies or developed for this study where necessary.

\section{Results}

A total of 856 responses were obtained through a convenience sampling approach. As shown in Table 3, Selangor, Johor and the Federal Territory of Kuala Lumpur indicate the highest percentage of response, which is 133 responses $(15.5 \%), 93$ responses $(10.9 \%)$ and 90 responses $(10.5 \%)$ respectively. The respondent characteristics are as follows: 59 percent were male and 41 percent were female; respondents ranged in age from 20 to 60 years, although a majority - 58.4 percent of respondents - were between 20-40 years old; 62.1 percent were the school leavers, certificate holders and undergraduate students, while 37.9 percent were graduate students. 
Table 3. Location-based consumers' response

\begin{tabular}{ccccc}
\hline Location & Frequency & Percent & Valid Percent & Cumulative Percent \\
\hline Perlis & 14 & 1.6 & 1.6 & 1.6 \\
Kedah & 75 & 8.8 & 8.8 & 10.4 \\
Perak & 56 & 6.5 & 6.5 & 16.9 \\
Pulau Pinang & 75 & 8.8 & 8.8 & 25.7 \\
Selangor & 133 & 15.5 & 15.5 & 41.2 \\
N. Sembilan & 45 & 5.3 & 5.3 & 46.5 \\
Melaka & 49 & 5.7 & 5.7 & 52.2 \\
Johor & 93 & 10.9 & 10.9 & 63.1 \\
Pahang & 44 & 5.1 & 68.2 \\
Terengganu & 33 & 3.9 & 3.9 & 72.1 \\
Kelantan & 40 & 4.7 & 4.7 & 76.8 \\
Sarawak & 55 & 6.4 & 6.4 & 83.2 \\
Sabah & 46 & 5.4 & 5.4 & 88.6 \\
W.P.Labuan & 3 & 0.4 & 0.4 & 88.9 \\
W.P.Kuala Lumpur & 90 & 10.5 & 10.5 & 99.4 \\
W.P.Putrajaya & 5 & 0.6 & 0.6 & 100.0 \\
Total & $\mathbf{8 5 6}$ & $\mathbf{1 0 0 . 0}$ & $\mathbf{1 0 0 . 0}$ &
\end{tabular}

Overall, there are five constructs representing the independent and dependent variables as portrayed in Figure 1. To validate the measures of the constructs, a series of Confirmatory Factor Analysis (CFA) using AMOS 20.0 was conducted to test the dimensionality, reliability and convergent validity of the measured items. CFA for the individual constructs were conducted at the initial stage - one measurement model per construct. In stage two, all constructs were simultaneously tested to obtain the overall measurement model. Table 4 shows the results of the overall measurement model containing factors for all constructs. The fit indices collectively show adequate fit of the measurement model with the data (Hair, Black, Babin, \& Anderson, 2010). In stage three, the final constructs were then simultaneously tested to obtain the structural model.

Table 4. Confirmatory factor analysis

\begin{tabular}{|c|c|c|c|c|c|c|}
\hline & Measured Items & $\chi^{2}$ & $p$ & AVE & A & $\begin{array}{l}\text { Standardized } \\
\text { Loadings }\end{array}$ \\
\hline & Attitude Towards Mobile Advertising & 8.16 & 0.00 & 0.67 & 0.91 & \\
\hline ATT1 & Mobile advertising is a good platform to get ideas about products and services & & & & & 0.88 \\
\hline ATT3 & Mobile advertising is favorable & & & & & 0.91 \\
\hline \multirow[t]{2}{*}{ ATT5 } & Engagement with mobile advertising is fun & & & & & 0.65 \\
\hline & Subjective Norms & 6.84 & 0.00 & 0.72 & 0.92 & \\
\hline SBN1 & $\begin{array}{l}\text { People who influence my behavior think I should purchase products and } \\
\text { services as advertised in mobile advertising }\end{array}$ & & & & & 0.81 \\
\hline SBN3 & $\begin{array}{l}\text { People in my community who engage with mobile advertising have more } \\
\text { prestige than those who do not }\end{array}$ & & & & & 0.88 \\
\hline \multirow[t]{2}{*}{ SBN5 } & $\begin{array}{l}\text { People in my community who engage with mobile advertising have a high } \\
\text { profile }\end{array}$ & & & & & 0.85 \\
\hline & Perceived Behavioral Control & 9.15 & 0.00 & 0.62 & 0.89 & \\
\hline PBC3 & $\begin{array}{l}\text { I have the knowledge necessary to purchase products and services as advertised } \\
\text { in mobile advertising }\end{array}$ & & & & & 0.86 \\
\hline
\end{tabular}


PBC4 Given the available resources and knowledge, it would be easy for me to engage with mobile advertising

PBC5 Guidance is available to me when I want to engage with mobile advertising Permission

PEM2 Mobile advertising with prior consent stimulate consumers purchase behavior $\begin{array}{llll}7.98 & 0.00 & 0.73 \quad 0.92\end{array}$

PEM4 Mobile advertising with prior consent minimizing risk associated with purchasing products and services

PEM5 Mobile advertising with prior consent instill confidence to perform purchase activities

\section{Purchase Intention}

PIN2 I will keep mobile advertising for future purchase reference

PIN4 I will consider the advertised products and services as the first choice

PIN6 I will contact the advertiser to obtain more information about products and services

Notes: 1. Measurement model fit indices: $\chi^{2}=142.25, \mathrm{df}=134, p<0.01, \mathrm{RMSEA}=0.063$, GFI $=0.94$; $\mathrm{IFI}=$ 0.93; NFI $=0.96$; TLI $=0.95 ; \mathrm{CFI}=0.95 ;$ AGFI $=0.93$ (Hair et al., 2010; Pallant, 2010).

2. This table reports the results of CFA after the deletions of some measured items.

3. $\chi^{2}=$ Chi-Square; $p=$ Significance Level; $\alpha=$ Cronbach's Alpha; AVE = Average Variance Extracted (Hair, et al., 2010).

All path coefficients from latent constructs to their corresponding measured indicators were appropriately high (standardized loadings ranging from 0.65 to 0.91 ) and significant. The reliability coefficients and Cronbach's Alpha all exceeded the recommended cut-off value of 0.60 (Nunnally, 1978; Pallant, 2010), showing evidence of acceptable reliability among the remaining items for all constructs. The Average Variance Extracted for all constructs were higher than the cut-off level of 0.50 suggesting an adequate convergent validity (Hair, et al., 2010).

The Structural Equation Modeling (SEM) of the conceptual model was tested using AMOS 20.0. The fit indices show an adequate fit between the conceptual model and the data obtained from the survey. Based on the values depicted by Table 3, the index of RMSEA, GFI, IFI, NFI, TLI, CFI and AGFI provide a sufficient amount of evidence to support the model (Hair, et al., 2010). The RMSEA was lower than the cut-off value of 0.08 , suggesting a good model fit (Hair, et al., 2010). The incremental fit indices of NFI, TLI, CFI and IFI were reported as above than 0.90 (Hair, et al., 2010; Ho, 2006; Joreskog \& Sorbom, 1988; Kline, 1998) hence providing further support to the model. In technical terms, the results indicate that there was no problem with the structural model. The results in Table 5 also show that all hypotheses received significant support based on the given data.

Table 5. Results of the model using SEM

\begin{tabular}{llcccc}
\hline \multicolumn{1}{c}{ Hypotheses } & $\begin{array}{c}\text { Direction / } \\
\text { Effect }\end{array}$ & Results & $\begin{array}{c}\text { Coefficient } \\
\text { Correlation }\end{array}$ & $\begin{array}{c}\text { Strength } \\
\text { Magnitude }\end{array}$ \\
\hline$H 1$ & $\begin{array}{l}\text { Attitude Towards Mobile Advertising } \rightarrow \text { Purchase } \\
\text { Intention }\end{array}$ & Positive & Supported & 0.615 & Large \\
$H 2$ & $\begin{array}{l}\text { Subjective Norms } \rightarrow \text { Purchase Intention } \\
\text { H3 }\end{array} \quad \begin{array}{l}\text { Perceived Behavioral Control } \rightarrow \text { Purchase } \\
\text { Intention }\end{array}$ & Positive & Supported & 0.383 & Large \\
H4 & $\begin{array}{l}\text { Attitude Towards Mobile Advertising } \rightarrow \text { Indirect Effect } \\
\text { Permission } \rightarrow \text { Purchase Intention }\end{array}$ & Supported & $0.559 / 0.427$ & Partial Mediation \\
\end{tabular}

Note: Structural model fit indices: $\chi^{2}=162.54, p=0.00 ; \mathrm{df}=152, p<0.01$, RMSEA $=0.067$, GFI $=0.95$; IFI $=$ 0.94; NFI $=0.96 ; \mathrm{TLI}=0.95 ; \mathrm{CFI}=0.96 ;$ AGFI $=0.94$ (Hair et al., 2010; Pallant, 2010). 


\section{Discussions and Implications}

This study adds to the growing mobile advertising literatures on Malaysian mobile phone users by examining their attitude and their intention to purchase products and services. The study reveals several implications for theory and practice relating to the determinants of the consumers' attitude derived from thirteen states and three federal territories in Malaysia. It also gives an idea about the relationship between the consumers' attitude towards mobile advertising and their intention to purchase products and services.

\subsection{Theoretical Implications}

The findings from this study extend the current mobile advertising literatures in two areas. First, the findings reported here illustrate the role of the dimensions in the Theory of Planned Behavior including the attitude, subjective norms and perceived behavioral control within the context of mobile advertising research in Malaysia. In the meantime, the dimension of the attitude towards mobile advertising played a significant role that influences the consumers' intention to purchase products and services. Second, the proposed model and instruments used in this study have been designed, measured and validated from the perspective of Malaysian consumers.

\subsection{Factors Affecting the Purchase Intention}

This study indicates that all proposed determinants have a significant influence on the Malaysian consumers' intention to purchase products and services. Taken together, the findings support past research that used TPB as the foundation of their research framework.

The dimension of the attitude towards mobile advertising was found to produce a positive relationship $(r=0.615)$ with the consumers' purchase intention. The result was quite different from the actual scenario that happens in Malaysia due to its infancy stage and the issue of trust that embedded in consumers' mind (Eng \& Masri, 2010; MCMC, 2010). However, the outcome was similar to the studies conducted in developed countries (Tsang, et al., 2004; Wong \& Tang, 2008). Perhaps, changes in the consumers' view could be due to the latest advancement of smartphones and other sophisticated mobile devices. The rapid development in telecommunication infrastructure also contributes to the changes (Chung et al., 2009; Mastor, Said, \& Marzuki, 2012a, 2012b; Utusan, 2012). The results have shown a brighter future for the mobile advertising industry in Malaysia. Due to its current condition, the intention to purchase the advertised products and services will become as high as developed countries such as Japan, USA, UK and Korea (Lane, 2010a, 2010b, 2010c).

The dimension of subjective norms was found to have a large positive effect $(r=0.524)$ on the consumers' purchase intention. The result was paralleled to the study conducted by Altuna and Konuk (2009) and Basheer and Ibrahim (2010) which claimed that consumers purchase intention was positively influenced by the Subjective Norms. Therefore, within the context of Malaysia, various types of promotional campaign designed by advertisers must include the element of relatives and friends to increase the effectiveness of mobile advertising which in turn stimulates the intention to purchase the advertised products and services.

The dimension of perceived behavioral control was found to have a medium positive effect $(r=0.383)$ on the consumers' intention to purchase. The result was slightly different from the previous study conducted by Ajzen (1991) and Taylor and Todd (1995a) which claimed that, perceived behavioral control has a large positive effect on the individual's behavioral intention. Within the context of Malaysia, the knowledge gained by the consumers together with the improvement in the technology facilitating conditions (Adham, et al., 2008; Chung, et al., 2009) slowly but steadily helps to boost consumers' intention to purchase products and services as advertised in mobile advertising.

The dimension of permission was found to partially mediate the relationship between consumers' Attitude towards Mobile Advertising and Purchase Intention. The results probably based on the current situation in Malaysia where the practice of prior permission has yet to become a business culture (Chung, et al., 2009). Also, the implementation of act related to privacy still not comprehensively executed in this country (Adham, et al., 2008).

Based on the response portrayed by the Malaysian consumers and results produced by the measurement and structural model, the Malaysian consumers' attitude towards mobile advertising is now changed. It thus offers a better opportunity for many advertisers to fully utilize the bright potential of mobile advertising. Future research might examine the moderating effect of demographic variables (i.e. age, gender and education) between the independent variables and consumers' intention to purchase products and services. Another area that can be examined is the effect of the consumers' attitude towards mobile advertising on the other behavioral intentions or actual behavioral actions. Further analysis can also be done in the other Asian countries to discover differences 
and similarities concerning the consumers' perception towards mobile advertising. Assessment in this area will be valuable for further development of mobile advertising in Asian countries.

\section{Conclusion}

This study has advanced knowledge by addressing the consumers' attitude towards mobile advertising, the role of prior permission and its impact on purchase intention. Based on the abstract ideas derived from the Theory of Planned Behavior (TPB) and the theory of Permission Marketing, it is believed that the research model is more realistic and reliable within the context of Malaysia. Data for this study were collected throughout Malaysia from a different range of age and gender. The findings provide useful guidelines for the telecommunication service providers (TSPs) and companies to evaluate their current mobile advertising practices while at the same time discovering areas that need to be changed for profitable returns in mobile advertising investment. In addition to that, this study also encourages the SMEs in Malaysia to utilize the great potential of mobile advertising. In this hypercompetitive world, businesses should react fast against the rapid changing business environment. Businesses should grab the opportunities and take the challenge to compliment their traditional advertising with mobile advertising.

\section{References}

Aaker, D. A., Kumar, V., \& Day, G. (1995). Marketing research. New York: Wiley.

Abernethy, A. M. (1991). Physical and mechanical avoidance of television commercials: An exploratory study of zipping, zapping and leaving. In R. Holman (Ed.), Proceedings of the American Academy of Advertising. Reno, NV.

Adham, K. A., Said, M. F., Ramlee, S., \& Hannien, S. (2008). e-Pay Malaysia: Asian expansion and challenges. Asian Journal of Case Research, 1(2), 101-129.

Ajzen, I. (1985). From intentions to actions: A theory of planned behavior. In J. Kuhl, \& J. Beckmann (Eds.), Action-control: From cognition to behavior. Heidelberg: Springer.

Ajzen, I. (1991). The theory of planned behavior. Organizational behavior and human decision processes, 50, 179-211. http://dx.doi.org/10.1016/0749-5978(91)90020-T

Ajzen, I. (1998). Attitudes, Personality and Behavior. Chicago, Illinois: The Dorsey Press.

Ajzen, I., \& Fishbein, M. (1977). Attitude-Behavior relations: A theoretical analysis and review of empirical research. Psychological Bulletin, 84(September), 888-918. http://dx.doi.org/10.1037/0033-2909.84.5.888

Ajzen, I., \& Fishbein, M. (1980). Understanding attitudes and predicting social behavior. NJ: Prentice-Hall.

Altuna, O. K., \& Konuk, F. A. (2009). Understanding consumer attitudes toward mobile advertising and its impact on consumers' behavioral intentions: A cross-market comparison of United States and Turkish consumers. International Journal of Mobile Marketing, 4(2), 43-51.

Ashraf, M. F., \& Kamal, Y. (2010). Acceptance of mobile marketing among university students. Mustang Journal of Business \& Ethics, 1, 9-29.

Austin, J. E. (1990). Managing in developing countries. New York: The Free Press.

Bagozzi, R. P. (1981). Attitudes, intentions and behavior: A test of some key hypotheses. Journal of Personality and Social Psychology, 41, 607-627. http://dx.doi.org/10.1037/0022-3514.41.4.607

Bagozzi, R. P., Wong, N., Abe, S., \& Gergami, M. (2000). Cultural and situational contigencies and the theory of reasoned action: Application to fast food restaurant consumption. Journal of Consumer Psychology, 9, 97-106. http://dx.doi.org/10.1207/S15327663JCP0902_4

Bamba, F., \& Barnes, S. J. (2007). SMS advertising, permission and the consumer: a study. Business Process Management Journal, 13(6), 815-829. http://dx.doi.org/10.1108/14637150710834578

Bandura, A. (1977). Social learning theory. Englewood Cliffs, NJ: Prentice Hall.

Bandura, A. (1978). The self system in reciprocal determinism. American Psychologist, 33, 344-358. http://dx.doi.org/10.1037/0003-066X.33.4.344

Bandura, A. (1986). Social foundations of thought and action: A social cognitive theory. Englewood Cliffs, NJ: Prentice Hall.

Bandura, A. (2001). Social cognitive theory of mass communication. Mediapsychology, 3(1), 265-299. http://dx.doi.org/10.1207/S1532785XMEP0303_03 
Barnes, \& Scornavacca, E. (2004). Mobile marketing: The role of permission and acceptance. International Journal of Mobile Communication, 2(2), 128-139. http://dx.doi.org/10.1504/IJMC.2004.004663

Baron, R., \& Byrne, D. (2000). Social Psychology (9th ed.). Boston: Ally \& Bacon.

Barwise, P., \& Strong, C. (2002). Permission based mobile advertising. Journal of Interactive Marketing, 16(1), 14-24. http://dx.doi.org/10.1002/dir.10000

Basheer, A. M., \& Ibrahim, A. M. (2010). Mobile marketing: examining the impact of trust, privacy, concern and consumers' attitudes on intention to purchase. International Journal of Business \& Management, 5(3), 28-41.

Bauer, Barnes, S. J., Reichardt, T., \& Neumann, M. M. (2005). Driving consumer acceptance of mobile marketing: A theoretical framework and empirical study. Journal of Electronic Commerce Research, 6(3), 181-192.

Beneke, J., Cumming, G., Stevens, A., \& Versfeld, M. (2010). Influences on attitude toward mobile text message advertisements: An investigation of South African youth. International Journal of Mobile Marketing, 5(1), 77-97.

Blackwell, R. D., Miniard, P. W., \& Engel, J. F. (2001). Consumer behavior (9th ed.). Ohio: USA.: South-Western Thomson Learning.

Carroll, A., Barnes, S. J., Scornavacca, E., \& Fletcher, K. (2007). Consumer perceptions and attitudes towards SMS advertising: recent evidence from New Zealand. International Journal of Advertising, 26(1), 79-98.

Chowdhury, H. K., Parvin, N., Weitenberner, C., \& Becker, M. (2006). Consumer attitude toward mobile advertising in an emerging market: An empirical study. International Journal of Mobile Marketing, 1(2), $33-42$.

Chung, Y. S., Suan, F. L. A., Manoharan, S., Kadir, A. A., Mohamed, N. M., Kamarudin, S. N., et al. (2009). Advertising development in Malaysia: Catching eyeballs in changing media. Cyberjaya, Selangor: Malaysia: Malaysian Communications and Multimedia Commission.

Churchill, G. A. J., \& Iacobucci, D. (2002). Marketing research: Methodological foundations. Mason, Ohio: South-Western Publishing.

Compeau, D. R., \& Higgins, C. A. (1995a). Application of social cognitive theory to training for computer skills. Information Systems Research, 6(2), 118-143. http://dx.doi.org/10.1287/isre.6.2.118

Compeau, D. R., \& Higgins, C. A. (1995b). Computer self-efficacy: Development of measure and initial test. MIS Quarterly, 19(2), 189-211. http://dx.doi.org/10.2307/249688

Cooper, \& Zmud, R. W. (1990). Information technology implementation research: A technological diffusion approach. Management Science, 36(2), 123-139. http://dx.doi.org/10.1287/mnsc.36.2.123

Davis, F., Bagozzi, R. P., \& Warshaw, P. R. (1989). User acceptance of computer technology: A comparison of two theoretical models. Management Science, 35(8), 982-1003. http://dx.doi.org/10.1287/mnsc.35.8.982

Denk, M., \& Hackl, M. (2004). Where does mobile business go? International Journal of Electronic Business, 2(5), 460-470. http://dx.doi.org/10.1504/IJEB.2004.005879

DOSM. (2011). Department of Statistics, Malaysia: Number of Transactions for Online Services (January December 2010). Retrieved May 10, 2011, from http://www.statistics.gov.my/portal/index.php?option=com_content\&view=article\&id=787\%3Anumber-of-t ransactions-for-online-services-january-december-2010\&catid=39\%3Afrontpage\&lang=en

Drossos, M., Giaglis, G. M., Lekakos, G., Kokkinaki, F., \& Stavraki, M. G. (2007). Determinants of effective SMS advertising: An experimental study. Journal of Interactive Advertising, 7(2), 1-23.

Dufrene, D. D., Engelland, B. T., Lehman, C. M., \& Pearson, R. A. (2005). Changes in consumer attitude resulting from participation in a permission email campaign. Journal of Current Issues and Research in Advertising, 27(1), 65-77. http://dx.doi.org/10.1080/10641734.2005.10505174

Eng, K. H., \& Masri, A. (2010). Communications and multimedia selected facts and figures. Retrieved October 20, 2010, from http://www.skmm.gov.my/link_file/facts_figures/stats/pdf/CM_Quarter2_2010.pdf

Evans, M., Jamal, A., \& Foxall, G. (2006). Consumer Behaviour. West Sussex, England: John Wiley \& Sons, Ltd. 
Fishbein, M., \& Ajzen, I. (1975). Belief, attitude, intention and behavior: An introduction to theory and research. Reading, MA, USA: Addison-Wesley.

Freeman, J. (2008). Mall Intercept Survey - General Overview. Retrieved January 18, 2012, from http://mallinterceptbmkt360.blogspot.com

Friedrich, R., Grone, F., Holbling, K., \& Peterson, M. (2009, March). The march of mobile marketing: New chances for consumer companies, new opportunities for mobile operators. Journal of Advertising Research, 54-61. http://dx.doi.org/10.2501/S0021849909090096

Frolick, M. N., \& Chen, L. D. (2004). Assessing m-commerce opportunities. Information System Management, 21(2), 53-61. http://dx.doi.org/10.1201/1078/44118.21.2.20040301/80422.8

Gao, Sultan, F., \& Rohm, A. J. (2010). Factors influencing Chinese youth consumers' acceptance of mobile marketing. Journal of Consumer Marketing, 27(7), 574-583. http://dx.doi.org/10.1108/07363761011086326

Godin, S. (1999). Permission marketing: Turning strangers into friends, and friends into customers. New York, USA: Simon \& Schuster.

Granbois, D. H., \& Summers, J. O. (1975). Primary and secondary validity of consumer purchase probabilities. Journal of Consumer Research, 1(4), 31-38. http://dx.doi.org/10.1086/208605

Hair, J. F., Black, W. C., Babin, B. J., \& Anderson, R. E. (2010). Multivariate Data Analysis - A Global Perspective. Upper Saddle River, New Jersey, USA: Pearson Education, Inc.

Hartwick, J., \& Barki, H. (1994). Explaining the role of user participation in information system use. Management Science, 40(4), 440-465. http://dx.doi.org/10.1287/mnsc.40.4.440

Ho, R. (2006). Handbook of univariate and multivariate data analysis and interpretation with SPSS. Boca Raton, Florida: Chapman \& Hall/CRC. http://dx.doi.org/10.1201/9781420011111

Hongwei, Y., Zhou, L., \& Liu, H. (2010). A comparative study of American and Chinese young consumers' acceptance of mobile advertising: A structural equation modeling approach. International Journal of Mobile Marketing, 5(1), 60-76.

Hoyer, W. D., \& MacInnis, D. J. (2004). Consumer behavior. New York: Houghton Mifflin.

Hulme, M., \& Peters, S. (2001). Me, my phone and I: The role of the mobile phone. Lancaster, UK: Teleconomy Research House.

Hung, S. Y., Ku, C. Y., \& Chang, C. M. (2003). Critical success factors of WAP services adoption: An empirical study. Electronic Commerce Research and Applications, 2, $42-60$. http://dx.doi.org/10.1016/S1567-4223(03)00008-5

Jaccard, J., King, W., \& Pomozal, R. (1977). Attitudes and behavior: An analysis of specificity of attitudinal predictors Human Relations, 30(September), 817-824. http://dx.doi.org/10.1177/001872677703000904

James, T. L., Griffiths, K., Smyrnios, K. X., \& Wilson, B. (2004). Mobile marketing: The role of permission and attitude on purchase intentions. Paper presented at the ANZMAC 2004: Marketing Accountabilities and Responsibilities, Wellington, New Zealand.

Jayawardhena, C., Kuckertz, A., Karjaluoto, H., \& Karjaluoto, H. (2009). Antecedents to permission based mobile marketing: an initial examination. European Journal of Marketing, 43(3/4), 473-499. http://dx.doi.org/10.1108/03090560910935541

Joreskog, K. G., \& Sorbom, D. (1988). PRELIS: A preprocessor for LISREL (2nd ed.). Mooresville: Scientific Software Inc.

Joseph, A. C., James McCullough, \& Reilly, M. (1985). Effects of unexpected situations on behavior-intention differences: A garbalogy analysis. Journal of Consumer Research, 12(September), 188-194.

Jun, J. W., \& Lee, S. (2007). Mobile media use and its impact on consumer attitudes toward mobile advertising. International Journal of Mobile Marketing, 2(1), 50-58.

Karjaluoto, H., Lehto, H., Leppaniemi, M., \& Jayawardhena, C. (2008). Exploring gender influence on customer's intention to engage permission-based mobile marketing. Journal of Electronic Markets, 18(3), 242-259. http://dx.doi.org/10.1080/10196780802265793

Katz, E., Hass, H., \& Gurevitech, M. (1973). On the use of the mass media for important things. American Sociological Review, 38(2), 164-181. http://dx.doi.org/10.2307/2094393 
Kautonen, T., Karjaluoto, H., Jayawardhena, C., \& Kuckertz, A. (2007). Permission-based mobile marketing and sources of trust in selected European markets. Journal of Systems and Information Technology, 9(2), 104-123. http://dx.doi.org/10.1108/13287260710839201

Kavassalis, P., Spyropoulou, N., Drossos, D., Mitrokostas, E., Gikas, G., \& Hatzistamatiou, A. (2003). Mobile permission marketing: Framing the market inquiry. International Journal of Electronic Commerce, $8(1)$, 55-79.

Kervin, J. B. (1992). Methods for business research. New York: Harper Collins Publishers Inc.

Khan, M. N., \& Allil, K. (2010). Determinants of mobile advertising adoption: A cross-country comparisan of India and Syria. International Journal of Mobile Marketing, 5(1), 41-59.

Kim, Heo, J., \& Chan-Olmsted, S. M. (2010). Perceived effectiveness and business structrure among advertising agencies: A case study of mobile advertising in South Korea. Journal of Media Business Studies, 7(2), 1-20.

Kline, R. B. (1998). Principles \& Practice of Structural Equation Modeling. New York: The Guilford Press.

Komulainen, H., Mainela, T., Tahtinen, J., \& Ulkuniemi, P. (2007). Retailers' different value perceptions of mobile advertising service. International Journal of Service Industry Management, 18(4), 368-393. http://dx.doi.org/10.1108/09564230710778146

Kotler, P., \& Armstrong, G. (2001). Principles of marketing (9th ed.). Upper Saddle River, NJ: Prentice-Hall.

Krishnamurthy, S. (2001). A comprehensive analysis of permission marketing. Journal of Computer-Mediated Communication, 6(2), 1-19.

Lane, N. (2010a). Asia Pacific: Powerhouse for mobile advertising. CA, USA: Smaato Inc.

Lane, N. (2010b). The USMA: The United States of mobile advertising. CA, USA: Smaato Inc.

Lane, N. (2010c). White paper on Europe's big five join the mobile advertising billionaires club. CA, USA: Smaato Inc.

Laszlo, J. (2009). The new unwired world: An IAB status report on mobile advertising. Journal of Advertising Research(March), 27-43. http://dx.doi.org/10.2501/S0021849909090035

Laudon, K. C. (1985). Environmental and institutional models of systems development: A national criminal history system. Communications of the ACM, 28(7), 728-740. http://dx.doi.org/10.1145/3894.3899

Lee, S. F., Tsai, Y. C., \& Jih, W. J. (2006). An empirical examination of customer perceptions of mobile advertising. Information Resources Management Journal, $19(4), \quad 39-55$. http://dx.doi.org/10.4018/irmj.2006100103

Leppaniemi, M., \& Karjaluoto, H. (2005). Factors influencing consumers' willingness to accept mobile advertising: a conceptual model. International Journal of Mobile Communication, 3(3), 197-212. http://dx.doi.org/10.1504/IJMC.2005.006580

Li, H. R., Edwards, S. M., \& Lee, J. H. (2002). Measuring the intrusiveness of advertisements: Scale development and validation. Journal of Advertising, 31(2), 37-47.

Lutz, R. J. (1985). Affective and cognitive antecedents of attitude towards the ad: A conceptual framework. In L. Alwitt, \& A. A. Mitchell (Eds.), Psychological processes and advertising effects. Hillsdale, NJ: Lawrence Erlbaum.

MAMPU. (2009). mySMS 15888: 1 nombor untuk perkhidmatan kerajaan. Retrieved May 10, 2011, from http://www.mysms.gov.my/dokumen/Direktori_mySMS.pdf

Maneesoonthorn, C., \& Fortin, D. (2006). Texting behavior and attitudes toward permission mobile advertising: An empirical study of mobile users' acceptance of SMS for marketing purposes. International Journal of Mobile Marketing, 1(1), 66-41.

Mastor, M. A. A., Said, R. M., \& Marzuki, N. (2012a, February 12th, 2012). 37 juta telefon bimbit di Malaysia. Mingguan Malaysia, p. 14.

Mastor, M. A. A., Said, R. M., \& Marzuki, N. (2012b, February 13th, 2012). Telefon pintar kegilaan masa kini. Utusan Malaysia, p. 13.

Mathieson, K. (1991). Predicting user intentions: Comparing the TAM with the theory of planned behavior. Information System Research, 2(3), 173-191. http://dx.doi.org/10.1287/isre.2.3.173

McDaniel, C., Lamb, C. W., \& Hair, J. F. (2006). Introduction to marketing (8th ed.). Mason, Ohio: Thomson 
South-Western.

McKenzie, \& Jurs, J. (1993). Planning, implementing, and evaluating health promotion programs. New York, USA: Macmillan Publications Co.

MCMC. (2009). MCMC annual report 2009: Broadbands towards 1Malaysia. Retrieved October 20, 2010, from http://www.skmm.gov.my/link_file/about_us/pdf/Web\%20Update\%20Annual\%20Report/SKMM_Annual_ Report_2009.pdf

MCMC. (2010). Charting Milestones in Service Delivery: Excellence Industry Performance Report 2009. Retrieved May 10, 2011, from http://www.skmm.gov.my/link_file/what_we_do/Research/pdf/IPR09.pdf

Mehta, A. (2000). Advertising attitudes and advertising effectiveness. Journal of Advertising Research, 40(3), 67-71.

Merisavo, M., Kajalo, S., Karjaluoto, H., Virtanen, V., Salmenkivi, S., Raulas, M., et al. (2007). An empirical study of the drivers of consumer acceptance of mobile advertising. Journal of Interactive Advertising, 7(2), $1-17$.

Merisavo, M., Karjaluoto, H., Virtanen, V., Salmenkivi, S., Raulas, M., \& Leppaniemi, M. (2010). An empirical study of the drivers of consumer acceptance of mobile advertising. Journal of Interactive Advertising, 7(2), 41-50.

Milne, G., \& Rohm, A. (2000). Consumer privacy and name removal across direct marketing channels: Exploring opt-in and opt-out alternatives. Journal of Public Policy and Marketing, 19(2), 238-249. http://dx.doi.org/10.1509/jppm.19.2.238.17136

Miniard, P. W., Obermiller, C., \& Page, T. J. (1983). A further assessment of measurement influences on the intention-behavior relationship. Journal of Marketing Research, 20(2), 206-212. http://dx.doi.org/10.2307/3151687

Mort, G. S., \& Drennan, J. (2007). Mobile communications: A study of factors influencing consumer use of m-services. Journal of Advertising Research, (September), 302-312. http://dx.doi.org/10.2501/S0021849907070328

Morwitz, V. G., Johnson, E., \& Schmittlein, D. (1993). Does measureing intent change behavior? Journal of Consumer Research, 20(1), 46-62. http://dx.doi.org/10.1086/209332

Mowen, J., \& Minor, M. (2001). Consumer Behavior: A Framework. New Jersey, USA: Prentice-Hall.

Muk, A. (2007). Consumers' intentions to opt in to SMS advertising: A cross-national study of young Americans and Koreans. International Journal of Advertising, 26(2), 177-198.

Muk, A., \& Babin, B. J. (2006). U.S. consumers' adoption - nonadoption of mobile SMS advertising. International Journal of Mobile Marketing, 1(1), 21-29.

NOKIA. (2002). New Nokia research shows consumers ready for m-marketing via mobile handsets. Retrieved November 4, 2010, from http://press.nokia.com/PR/200201/846567_5.html

NST. (2009, July 22). Mobile phone advertising the new growth area: 4As. New Straits Times. Retrieved from http://www.btimes.com.my/articles/4a/Article/

Nunnally, J. (1978). Psychometric theory. New York: McGraw-Hill.

Nysveen, H., Pedersen, P. E., \& Thorbjornsen, H. (2005). Intentions to use mobile services: Antecedents and cross-service comparisons. Journal of the Academy of Marketing Science, 33(3), 330-346. http://dx.doi.org/10.1177/0092070305276149

Okazaki, S. (2004). How do Japanese consumers perceive wireless ads? A multivariate analysis. International Journal of Advertising, 23, 429-454.

Okazaki, S., Li, H., \& Hirose, M. (2009). Consumer privacy concerns and preference for degree of regulatory control. Journal of Advertising, 38(4), 63-77. http://dx.doi.org/10.2753/JOA0091-3367380405

Pallant, J. (2010). SPSS survival manual (4th ed.). New York: McGraw-Hill Education.

Park, T., Shenoy, R., \& Salvendy, G. (2008). Effective advertising on mobile phones: a literature review and presentation of results from 53 case studies. Behaviour \& Information Technology, 27(5), 355-373. http://dx.doi.org/10.1080/01449290600958882

Pavlou, P. A., \& Stewart, D. W. (2000). Measuring the effects and effectiveness of interactive advertising: A 
research agenda. Journal of Interactive Advertising, 1(1). Retrieved from http://www:jiad.org

PEMANDU. (2010). ETP: Chapter 13 - Communications, content and infrastructure Retrieved from http://etp.pemandu.gov.my/upload/etp_handbook_chapter_13_communications_content.pdf

Peng, B. (2006). Mobile marketing - The Chinese perspective. International Journal of Mobile Marketing, 1(2), 50-59.

Radder, L., Pietersen, J., Wang, H., \& Han, X. (2010). Antecedents of South African high school pupils' acceptance of universities SMS advertising International Business \& Economics Research Journal, 9(4), 29-39.

Ratten, V., \& Ratten, H. (2007). Social cognitive theory in technological innovations. European Journal of Innovation Management, 10(1), 90-108. http://dx.doi.org/10.1108/14601060710720564

Reibstein, D. J. (1978). The prediction of individual probabilities of brand choice. Journal of Consumer Research, 5(3), 163-168. http://dx.doi.org/10.1086/208727

Rettie, R., Grandcolas, U., \& Deakins, B. (2005). Text message advertising: Response rates and branding effects. Journal of Targeting, Measurement and Analysis for Marketing 13(4), 304-312. http://dx.doi.org/10.1057/palgrave.jt.5740158

Rich, R., \& Hancock, L. (2005). The Mall Intercept: A Social Norms Marketing Research Tool: National Social Norms Resource Centre.

Roscoe, J. T. (1975). Fundamental Research Statistics for Behavioral Sciences (2nd ed.). New York: Holt, Rinehart and Winston.

Rose, E. A. (2006). An examination of the concern for information privacy in the New Zealand regulatory context. Information and Management, 43(3), 322-335. http://dx.doi.org/10.1016/j.im.2005.08.002

Rozana, S. (2009, February 15). Still long way to go for mobile advertising. The New Straits Times. Retrieved from

http://technu.nst.com.my/Current_News/techNu/Monday/Spotlite/20090215201321/Article/index_html

Schlosser, A. E., Shavitt, S., \& Kanfer, A. (1999). Survey of internet users' attitudes toward internet advertising. Journal of Interactive $\quad$ Marketing, $34-54$. http://dx.doi.org/10.1002/(SICI)1520-6653(199922)13:3<34::AID-DIR3>3.0.CO;2-R

Sekaran, U. (2003). Research methods for business: A skill building approach (4th ed.). New York: John Wiley \& Sons, Inc.

Sheppard, B. H., Hartwick, J., \& Warshaw, P. R. (1988). The Theory of Reasoned Action: A meta-analysis of past research with recommendations for modifications and future research. Journal of Consumer Research, 15(3), 325-343. http://dx.doi.org/10.1086/209170

Shimp, T. A., \& Kavas, A. (1984). The theory of reasoned action applied to coupon usage. Journal of Consumer Research, 11(3), 795-809. http://dx.doi.org/10.1086/209015

Solomon, M. R. (2004). Consumer behavior: Buying, having and being. Upper Saddle River, NJ: Pearson Education.

Spurgeon, C. (2005). Losers and lovers: Mobile phone services advertising and the new media consumer/producer. Journal of Interactive Advertising, 5(2), 47-55.

Taylor, S., \& Baker, T. L. (1992). An assessment on the relationship between service quality and consumer satisfaction in the formation of consumers' purchase intentions. Journal of of Retailing, 70(2).

Taylor, S., \& Todd, P. A. (1995a). Assesing IT usage: The role of prior experience. MIS Quarterly, 19(2), 561-570. http://dx.doi.org/10.2307/249633

Taylor, S., \& Todd, P. A. (1995b). Understanding information technology usage: A test of competing models. Information Systems Research, 6(4), 144-176. http://dx.doi.org/10.1287/isre.6.2.144

Teo, T. S. H., \& Pok, S. H. (2003). Adoption of WAP-enabled mobile phones among internet users. Omega, 31, 483-498. http://dx.doi.org/10.1016/j.omega.2003.08.005

Thomas, J. M., Ellen, P. S., \& Ajzen, I. (1992). A comparison of the Theory of Planned Behavior and the Theory of Reasoned Action. Personality and Social Psychology Bulletin, 18(February), 3-9.

Triandis, H. C. (1971). Attitude and attitude change. New York: Wiley. 
Triandis, H. C. (1979). Values, attitudes and interpersonal behavior. In Nebraska Symposium on Motivation: Beliefs, Attitudes, and Values. Lincoln, NE: University of Nebraska Press.

Tripathi, S. N., \& Siddiqui, M. H. (2008). Effectiveness of mobile advertising: The Indian scenario. Journal for Decision Makers, 33(4), 47-59.

Tsang, M. M., Ho, S. C., \& Liang, T. P. (2004). Consumer attitudes toward mobile advertising: An empirical study. International Journal of Electronic Commerce, 8(3), 65-78.

Utusan. (2012, July 18). Malaysia dijangka catat transaksi e-dagang RM1.9b. Utusan Malaysia, pp. 17-29.

Varshney, U. (2003). Location management for mobile commerce applications in wireless internet environment. ACM Transactions on Internet Technology, 3(3), 236-255. http://dx.doi.org/10.1145/857166.857169

Vatanparast, R., \& Asil, M. (2007). Factors affecting the use of mobile advertising. International Journal of Mobile Marketing, 2(2), 21-34.

Venkatesh, V., \& Davis, F. D. (2000). A theoretical extension of the technology acceptance model: Four $\begin{array}{lllll}\text { longitudinal field } & \text { studies. }\end{array}$ http://dx.doi.org/10.1287/mnsc.46.2.186.11926

Venkatesh, V., Morris, M. G., Davis, G. B., \& Davis, F. D. (2003). User acceptance of information technology: Toward a unified view. MIS Quarterly, 27(3), 425-478.

Wang, S., \& Wang, H. (2005). A location based business service model for mobile commerce. International Journal of Mobile Communication, 3(4), 339-349. http://dx.doi.org/10.1504/IJMC.2005.007022

Warshaw, P. R. (1980). Predicting purchase and other behaviors from general and contextually specific intentions. Journal of Marketing Research, 17(1), 26-33. http://dx.doi.org/10.2307/3151113

WEF. (2010). World economic forum annual report 2009 - 2010 Switzerland: World Economic Forum.

Weilbacher, W. M. (2003). How advertising affects consumers. Journal of Advertising Research, 43(2), 230-234.

Whitaker, L. (2001). Ads Unplugged. American Demographics, 23(6), 30-34.

Wong, M. M. T., \& Tang, E. P. Y. (2008). Consumers' attitude towards mobile advertising: The role of permission. Review of Business Research, 8(3), 181-187.

Yang, K. C. C. (2007). Exploring factors affecting consumer intention to use mobile advertising in Taiwan. Journal of International Consumer Marketing, 20(1), 33-49. http://dx.doi.org/10.1300/J046v20n01_04

Zhang, J., \& Mao, E. (2008). Understanding the acceptance of mobile SMS advertising among young Chinese consumers. Psychology \& Marketing, 25(8), 787-805. http://dx.doi.org/10.1002/mar.20239 